Article

\title{
Total Count of White Blood Cells in Adult Male Smokers
}

\author{
Islam $\mathrm{MM}^{1}$, Amin $\mathrm{MR}^{2}$, Begum $\mathrm{S}^{3}$, Akther $\mathrm{D}^{4}$, Rahman $\mathrm{A}^{5}$
}

The present study was carried out to observe the changes in total count in WBC in cigarette smokers. The study population consisted of 105 adult male smokers and non-smokers, aged $20 \sim 40$ years, from different socio-economic classes. Among them, 30 apparently healthy non-smokers were taken as control . 75 apparently healthy smokers, who had the history of smoking of one or more cigarette per day, regularly for at least last one year, were taken as the study group. Smokers were again subdivided into three categories according to the number of cigarettes they consumed per day. For statistical analysis unpaired " $\mathrm{t}$ " test was used for comparison. Mean \pm SD of Total count of WBC in non smokers and smokers were $7501.66 \pm 929.4 / \mathrm{mm}^{3}$ and $9171.3 \pm 1037.7 / \mathrm{mm}^{3}$ respectively. Smokers had significantly $(\mathrm{P}<0.001)$ higher WBC counts than non-smokers. In addition, WBC count was found increased with intensity of smoking. The smokers who were smoking e" 20 cigarettes per day had the higher total WBC count than those who were smoking lesser.

The findings of the present study suggest that cigarette smoking may cause increased the total count of WBC, which may predict high risk for some fatal diseases.

Key words: Cigarette Smoking; White Blood Cell; Adult Male

J Bangladesh Soc Physiol. 2007 Dec;(2): 49-53

For author affiliations, see end of text.

http://www.banglajol.info/index.php/JBSP

\section{Introduction}

7 obacco is the second major cause of death in the world. It is currently responsible for the death of one in ten adults' worldwide (about 5 million deaths each year). If current smoking patterns continue, it will cause some 10 million deaths each year by 2020 .

Half the people that smoke today - that is about 650 million people - will eventually be killed by tobacco. ${ }^{1}$ The Expert Committee observed that tobacco related diseases are rising in developing countries. $^{2}$

In 2003, the smoking prevalence in Bangladesh, among adults was $54.8 \%$ in males and $16.6 \%$ in females. The prevalence of smoking in age group $18-29$ years, $30-39$ years, $40-49$ years are $36.3 \%$, $64.2 \%$, and $70.8 \%$ respectively. ${ }^{3}$

J Bangladesh Soc Physiol. 2007 Dec;(2): 49-53.
Infection and inflammation may contribute to vascular injury and atherogenesis. Inflammation may also promote atherosclerotic plaque rupture and thrombosis. Leucocytes, or white blood cells, may serve as an important biomarker for these disease processes. ${ }^{4}$

Inflammation is currently considered to play a central role in carcinogenesis, a hypothesis that has been addressed by assessing white blood cell count as a predictor of risk for cancer. ${ }^{5}$ Chronic inflammation has been hypothesized to play a role in the pathogenesis of several cancers. ${ }^{6}$

The WBC count can be used to predict mortality from all causes and from ASCVD (atherosclerotic cardiovascular diseases), ${ }^{5}$ myocardial infarction, ${ }^{7}$ ischemic heart disaease. ${ }^{8}$ Elevated WBC count is associated with increased 
risk of Cerebrovascular Disease, ${ }^{4}$ cancer mortality, ${ }^{6}$ and an independent risk factor for carotid atherosclerosis. $^{9}$

In this study, we hypothesized that cigarette smoking can alter the total count of WBC and level of increased WBC count may be associated with severity of smoking.

\section{Methods}

This cross sectional study, was carried out in the department of Physiology of the Dhaka Medical College from July 2005 to June 2006. Total 105 apparently healthy subjects age ranged from 20 40 years were selected, of whom 30 were non smokers (control - Group A) and 75 were smokers (experimental - Group B) who smoked for at least last one year. The smokers were again sub-grouped into 3 categories accordingly to the number of cigarette smoked per day (Group $\mathrm{B}_{1}$ : Consisted of 25 smokers consuming 1 9 cigarettes / day; Group $\mathrm{B}_{2}$ : Consisted of 25 smokers consuming 10 19 cigarettes/day; Group $\mathrm{B}_{3}$ : Consisted of 25 smokers consuming e” 20 cigarettes / day). They were selected from different areas of Dhaka city and different socioeconomic classes.

Subjects suffering from any acute or chronic respiratory illness, hypertension, diabetes mellitus, angina, endocrine, hepatic, allergic disorders, any infectious or debilitating illness etc. and subjects with history of recent hospitalization and surgery were excluded. Persons taking the drugs such as antibiotic, steroids, thiazide diuretics, aspirin etc. or taking radiotherapy and subjects who drink alcohol were also excluded. Passive smokers were not included for control group.

All the subjects were explained about the aims and objectives of the study and the test procedures were briefed and written consent was taken before performing the test. A detailed history of smoking habit and health of each subject was obtained by using a pre-tested questioner and clinical examination sheet.
Clinical examination of these subjects were done on the first day of the visit. The subjects were advised to fast overnight and not to engage in physical exercise and smoking before reporting on the next morning.

On the reporting day, the blood samples were collected at the morning between 8.00 to 9.00 am. with all aseptic (70\% alcohol) precaution. 2 $\mathrm{ml}$ venous blood was drawn and it was mixed with the anticoagulant- EDTA. WBC count were done within 5 hours of sample collection.

With the collected samples total count of WBC was done by Manual method (Visual haemocytometer method) for each study subjects in the laboratory of Physiology of Dhaka Medical College and Hospital, Dhaka.

After the collection data were checked, verified, edited for consistency to reduce error. All the results of laboratory investigations were loaded in computerized SPSS 12.0 programmer and statistical significance were analyzed by unpaired student's “t” test.

\section{Results}

Results were expressed as mean \pm SD (Standard Deviation).

The results are shown in Table-I .

The means $( \pm \mathrm{SD})$ of total count of WBC were $7502 \pm 929$ and $9171 \pm 1038$ per $\mathrm{mm}^{3}$ of blood in group A and group $\mathrm{B}$ respectively. Again the means $( \pm$ SD) total count of WBC were $8928 \pm$ 1084, $9038 \pm 960 / \mathrm{mm}^{3}, 9548 \pm 998$ per $\mathrm{mm}^{3}$ of blood in $\mathrm{B}_{1}, \mathrm{~B}_{2}$ and $\mathrm{B}_{3}$ groups respectively.

The difference of means $( \pm \mathrm{SD})$ of total count of WBC were significant $(\mathrm{p}<0.001)$ between group $\mathrm{A}$ and $\mathrm{B}$.

The results were also significant between group $A$ and smoker's group $\mathrm{B}_{1}(\mathrm{p}<0.001), \mathrm{B}_{2}(\mathrm{p}<0$ .001), $\mathrm{B}_{3}(\mathrm{p}<0.001)$.

Again the differences of means $( \pm \mathrm{SD})$ of total count of WBC among the smokers groups $\mathrm{B}_{1}$ vs. $B_{2}(p>0.05), B_{2}$ vs. $B_{3}(p>0.05)$ were not statistically significant. But the difference between $B_{1}$ vs. $B_{3}(p<0$.05) was statistically significant.

J Bangladesh Soc Physiol. 2007 Dec;(2): 49-53. 
Table - I : Mean \pm SD of total count of WBC in different groups. $(n=105)$

\begin{tabular}{lccc}
\hline Groups & $\mathrm{N}$ & $\begin{array}{c}\text { Mean thousands } \\
/ \mathrm{mm}^{3}\end{array}$ & $\begin{array}{c}\text { Standard } \\
\text { Deviation }\end{array}$ \\
\hline A & 30 & 7501.66 & \pm 929.44 \\
& & $(5650-9950)$ & \\
B & 75 & 9171.33 & \pm 1037.7 \\
& & $(6600-12000)$ & \\
B1 & 25 & 8928.00 & \pm 1084.36 \\
& & $(6600-11650)$ & \\
B2 & 25 & 9038.0000 & \pm 959.84 \\
& & $(7250-10800)$ & \\
B3 & 25 & 9548.0000 & \pm 997.54 \\
& & $(8300-12000)$ & \\
\hline
\end{tabular}

Statistical analysis

\begin{tabular}{lc}
\hline Groups & P values \\
\hline A vs. B & $0.001^{*}$ \\
A vs. $B_{1}$ & $0.0001^{* * *}$ \\
A vs. $B_{2}$ & $0.0001^{* * *}$ \\
A vs. $B_{3}$ & $0.0001^{* * *}$ \\
$\mathrm{~B}_{2}$ vs. $B_{3}$ & $0.072^{\mathrm{ns}}$ \\
$\mathrm{B}_{-}$vs. $\mathrm{B}_{3}$ & $0.041^{\mathrm{ns}}$ \\
$\mathrm{B}_{1}$ vs. $\mathrm{B}_{2}$ & $0.71^{\mathrm{ns}}$ \\
\hline
\end{tabular}

, $* * *=\mathrm{p}<0.001 *=\mathrm{p}<0.05$ ns $=$ nonsignificant.

\section{Discussion}

The mean total count of WBC in the present study was significantly $(\mathrm{p}<0.001)$ higher in smokers than non-smokers. This finding is consistent with several other investigators. $6,9,10-$ 16,28

Smith ${ }^{14}$ et al. observed that men and women, those who were current cigarette smokers had mean total WBC counts about $20-25 \%$ higher than non smokers. ${ }^{30}$

In this study it was also seen that WBC count increases with intensity of smoking. The smokers who were smoking $\geq \square 20$ cigarettes had the higher total WBC count compared to those smoked lesser number cigarettes.

Howell, ${ }^{13}$ reported that the mean leukocyte count was more than $1,000 / \mathrm{cu} \mathrm{mm}$ greater in male cigarette smokers, aged 40 to 54, than in nonsmokers. Corre ${ }^{29}$ et al. confirmed Howell's finding. The result of present study had greater similarity with the finding of Friedman ${ }^{30}$ They suggested, smoking induced increased leukocyte count might be due to nicotine-induced release of catecholamines, which could raise the leukocyte count. He also stated that the irritant effect of cigarette smoke on respiratory tree with resultant inflammation might be a contributory factor for higher WBC count which may also be the cause of higher WBC count in our study.

Smokers do have increase leukocyte count which might forecast the possible high risk for developing fatal such as, cancer, cardiovascular, cerebrovascular, respiratory diseases in these group of population.

\section{Acknowledgement}

This study was financially assisted partly by Dhaka Medical College, Dhaka. The authors thank the staffs of the physiology department of Dhaka Medical College and all those who volunteer as subjects for the study.

\section{Author Affiliations}

* 1. Mohammed Montasir Islam, Assistant Professor and Head of the Department of Physiology, Central Medical College, Comilla, Bangladesh

2. Md Ruhul Amin, Professor and Head of the Department, Physiology, Dhaka Medical College, Dhaka, Bangladesh

3. Shameema Begum, Assistant Professor, Department of Physiology, Dhaka Medical College, Dhaka, Bangladesh

4. Dilruba Akther, Lecturer, Department of Physiology, Holy family Red Crescent Medical College, Dhaka, Bangladesh

5. Abedur Rahman, Lecturer, Department of Physiology, Dhaka Medical College, Dhaka, Bangladesh

* For correspondence 


\section{Article}

\section{References}

1. WHO. Tobacco Free Initiative (TFI), 2006. Why is tobacco a public health priority? Available from: http:/ /www.who.int/tobacco/en/2. Nedd Willard. Tobacco: Third World warning. WHO Chronicle1983;37(3):86.

3. WHO Global InfoBase Online: National/ Subnational Country Profiles: Bangladesh. Available from: http:// www.who.int/ncd----_surveillance/infobase/web/ InfoBasePolicyMaker/reports/reportVi...

4. David W. Brown, Earl S. Ford, Wayne H. Giles, Janet B. Croft, Lina S Balluz, and Ali H. Mokdad. Association between White Blood Cell Count and Risk for Cerebrovascular Disease Mortality: NHANES II Mortality Study, 1976-1992. Ann Epidemiol 2004;14:425-430.

5. Sun Ha Jee, Jung Young Park, Hyon-Suk Kim, Tae Young Lee, and Jonathan M. Samet. White Blood Cell Count and Risk for All Cause, Cardiovascular, and Cancer Mortality in a Cohort to Koreans. Am J Epidemiol 2005;162:1062-1069.

6. Thomas P. Erlinger, Paul Muntner, and Kathy J. Helzlsouer. WBC Count and the Risk of Cancer Mortality in a National Sample of U.S. Adults: Results from the second National Health and Nutrition Examination Survey Mortality Study. Cancer Epidemiol, Biomarkers \& Prev 2004;13(6):1052-6.

7. Julia B. Zalokar, Jacques L. Richard, and Jean R. Claude. Leukocyte Count, Smoking, and Myocardial Infarction. The New Eng J Med 1981;304:465-68.

8. Peter M. Sweetnam, Hugh F. Thomas, John W. G. Yarnell, Ian A. Baker, and Peter C. Elwood. Total and Differential Leukocyte Counts as Predictors of Ischemic Heart Disease: The Carephilly and Speedwell Studies.

9. Nobukazu Ishizaka, Yuko Ishizaka, Ei-ichi Toda, Hideki Hashimoto, Ryozo Nagai, Minoru Yamakado. Association between white blood cell count and carotid arteriosclerosis in Japanese smokers. Atherosclerosis 2004;175:95-100.

10. Mac Aghaji, Ree Nnabuko, C Uzuegbunam, I C A Oyeka. The relationship of White Blood Cell and Platelet Counts to cigarette smoking in adult Nigerians. Cent Afr J Med 1990;36(11):273-8.

11. Elfrieke D. Van Tiel, Petra HM. Peeters, Henriette A. Smit, Nico JD. Nagelkerke, A. Jeanne M. Vanloon, Diederik E. Grobbee et al. Quitting Smoking May Restore Hematological Characteristics within Five Years. Ann Epidemiol 2002;12:378-388.
White Blood Cells in Male Smokers

12. Norman Helman, and Lawrence S. Rubenstein. The Effects of Age, Sex, and Smoking on Erythrocytes and Leukocytes. Am J Clin Path 1975;63:35-44.

13. Howell RW. Smoking Habits and Laboratory Tests. The Lancet 1970;2:152-153.

14. Megan R. Smith, Ann-Louise Kinmonth, Robert N. Luben, Sheila Bingham, Nicholas E. Day, Nicholas J Wareham et al Smoking status and differential white cell count in men and women in the EPIC-Norfolk population. Atherosclerosis 2003;169:331-337.

15. Gary D. Friedman, And Abraham B. Siegelaub. Changes After Quitting Cigarette Smoking. Circulation 1980;61(4):716-723.

16. Yarnell JWG, Sweetnam PM, Rogers S, Elwood PC, Bainton D, Baker IA et al. Some long term effects of smoking on the haemostatic system: a report from the Carephilly and Speedwell Collaborative Surveys.

17. Takahisa Kondo, Mutsuharu Hayashi, Kyosuke Takeshita, Yasushi Numaguchi, Koichi Kobayashi, Shigeo Iino et al. Smoking Cessation Rapidly Increases Circulating Progenitor Cells in Peripheral Blood in Chronic Smokers. Arteriscler Thromb Vasc Biol. 2004;24:1442-1447.

18. Akbas, E. Derici, F. Soylemez, A. Kanik and F. Polat. An investigation of effects of toluene and cigarette smoking on some blood parameters and lymphocyte life span. Cell Biology and Toxicology 2004;20: 33-40.

19. Suntaree Apibal, Prasit Kisukapan, Spain Uneanong, Siriporn Chitaganone, Somchai Rattanasrithong, Surangrat Srisurapanon et al. The Effects of Cigarette Smoking on Peripheral Blood Leukocytes and Lymphocyte Subpopulations: An Urban PopulationBased Study in Thailand. J Med Assoc Thai 2000;83 supple.(1):S109-113.

20. Erik Juel Jensen, Bente Pedersen, Ruben Frederiksen, Ronald Dahl. Prospective study on the effect of smoking and nicotine on leukocyte blood counts and relation between blood leucocytes and lung function. Thorax 1995;53:784-789.

21. Schaberg, C. Theilacker, O. T. Nitschke, and H. Lode. Lymphocyte Subsets in Peripheral Blood and Smoking Habits. Lung 1997;175:387-394.

22. David S. Freedman, W. Dana Flanders, Joseph J. Barboriak, Ann M. Malarcher and Lee Gates. Cigarette Smoking and Leukocyte Subpopulations in Men. Ann Epidemiol 1996;6:299-306.

J Bangladesh Soc Physiol. 2007 Dec;(2): 49-53. 
23. J oel Schwartz, and Scott T. Weiss. Cigarette Smoking and Peripheral Blood leukocyte Differentials. Ann Epidemiol 1994;4:236-242.

24. David J. Tollerud, Linda Morris Brown, William A. Blattner, Dean L.Mann, Luba Pankiw-Trost, and Robert N. Hoover. T Cell Subsets in Healthy Black Smokers and Nonsmokers. Am Rev Respir Dis 1991;144:612-616.

25. David J. Tollerud, Jeffrey W. Clark, Linda Morris Brown, Carolyn Y. Neuland, Dean L. Mann, Luba K. Pankiw-Trost et al. The Effects of Cigarette Smoking on T Cell Subsets: A Population-based Survey of Healthy Caucasians. Am Rev Respir Dis 1989;139:1446-1451.

26. Tell GS, Grimm RH, Vellar OD, and Theodorsen L. The relationship of white cell count, platelet count, and hematocrit to cigarette smoking in adolescents: the Oslo Youth Study. Circulation 1985;72(5):971-974.

27 . Taylor RG, Gross E, Joyce H, Holland F, Pride NB. Smoking, allergy, and the differential white blood cell count. Thorax 1985;40:17-22.

28. Hugh Parry, Sheldon Cohen, Janet E. Schlarb, David A. J. Tyrrell, Andrew Fisher, Michael A. H. Russell et al. Smoking, Alcohol Consumption, and Leukocyte Counts. Am J Clin Pathol 1997;107(1):64-67.

29. Corre F, Lellouch J, Schwartz D. Smoking and leucocyte counts: Results of an epidemiological survey. Lancet 1971;2:632-34.

30. Friedman GD, Siegelaub AB, Seltzer CC, Feldman R, Collen MF. Smoking habits and the leukocyte count. Arch Environ Health. 1973;26:137-43. 